\title{
Targeted Mutation
}

National Cancer Institute

\section{Source}

National Cancer Institute. Targeted Mutation. NCI Thesaurus. Code C48668.

A mutation created in a gene at a specific location. Targeted mutations are frequently generated in the laboratory to investigate the influence of inactivation of a particular gene product. 